\title{
System jakości stosowany w IPS „TABOR” i kompetencje techniczne gwarancją utrzymania wiarygodności współpracy z klientami
}

\begin{abstract}
$W$ artykule przedstawiono zakres i tematyke prac Instytutu oraz scharakteryzowano klientów i ich oczekiwania. Omówiono występujace problemy $i$ wymagania $w$ aspekcie jakości prac badawczo-rozwojowych. Przedstawiono strukturę zintegrowanego systemu jakości obejmujacego kompleksowo działalność Instytutu i pozwalajaca realizować Politykę Jakości Instytutu między innymi w zakresie oczekiwań i zadowolenia klienta.
\end{abstract}

\section{Wstęp}

Instytut Pojazdów Szynowych „TABOR” w Poznaniu jest jednostką badawczo - rozwojową o ponad sześćdziesięcioletniej tradycji w branży pojazdów szynowych. Kontynuuje dorobek powstałego w roku 1945 Biura Konstrukcyjnego, przekształconego w roku 1973 w Ośrodek Badawczo - Rozwojowy, wzbogacony od roku 1977 o bazę badawczą. W roku 2000 Ośrodek uzyskał status Instytutu działającego na podstawie ustawy o JBR.

Przeważająca ilość pojazdów szynowych w kraju, zarówno kolejowych jak i tramwajowych a także na bocznicach zakładów przemysłowych stanowi dorobek intelektualny i techniczno- naukowy Instytutu. Dorobek ten dotyczy też znacznej ilości taboru wyprodukowanego przez przemysł krajowy na eksport. Aktualnie Instytut „TABOR” rozwija nowe rozwiązania $\mathrm{w}$ transporcie kombinowanym $\mathrm{w}$ zakresie nowoczesnych technologii transportu oraz $\mathrm{w}$ modernizacji eksploatowanego dotychczas taboru.

Złożoność zagadnień technicznych oraz wymagania klientów determinowane mechanizmami rynkowymi wymagają od wykonawcy prac badawczorozwojowych wiedzy, kompetencji i doświadczenia oraz szybkości działania. Jest to wymaganie trudne, zważając na specyfikę prac koncepcyjnych, wymagającą spokojnych i wyważonych analiz. Dla realizacji tych wymagań wdrożono w Instytucie system jakości preferujący uporządkowane, zaplanowane i systematyczne działania. W artykule podano zasadnicze elementy tego systemu.

\section{System zarządzania jakością w IPS „TABOR” 2.1 Zakres i tematyka prac}

Zakres działania Instytutu obejmuje całokształt zagadnień dotyczących pojazdów szynowych, łącznie z transportem szynowo-drogowym. Dotyczy przewoźników kolejowych, przemysłowych i tramwajowych oraz metra.
Tematyka obejmuje: prace projektowe, konstrukcyjne, rozwojowe i badawcze oraz produkcję nowych rozwiązań podzespołów mających zastosowanie w pojazdach modernizowanych, montaż wyspecjalizowanych podzespołów prototypowych oraz obsługę serwisową $w$ ramach nadzoru autorskiego, wdrożenie $i$ techniczne dopracowywanie rozwiązań a w szczególności:

1. Projektowanie lokomotyw, wagonów osobowych, towarowych, specjalnych, zespołów trakcyjnych, autobusów szynowych, tramwajów, metra i pojazdów szynowo-drogowych.

2. Projektowanie rozwiazań modernizacyjnych aktualnie eksploatowanych pojazdów szynowych $w$ zakresie koncepcji, dokumentacji $i$ nowych podzespotów.

3. Projektowanie nowych podzespołów wyposażenia pojazdów szynowych zgodnie z aktualnymi trendami $i$ wymaganiami.

4. Rozwój rozwiazań i systemów pojazdów szynowo-drogowych do transportu masowego- transport kombinowany, bimodalny.

5. Rozwój rozwiazań i systemów pojazdów szynowo- drogowych o przeznaczeniu ratunkowym $i$ przegladowo-konserwacyjnym.

6. Rozwiqzywanie bieżacych problemów występujacych $w$ pojazdach szynowych $z$ uwzględnieniem wymagań dotyczqcych wysokich prędkości oraz bezpieczeństwa i komfortu podróżowania w tym: diagnozowanie, ekspertyzy, obliczenia, analizy, opinie i oceny zwiqzane z eksploatacja, awariami i technologia napraw.

7. Produkcja jednostkowa $i$ matoseryjna nowoopracowanych nietypowych podzespołów wyposażenia pojazdów szynowych.

8. Instalowanie prototypowych podzespołów w modernizowanych pojazdach szynowych. 
9. Serwisowanie wyprodukowanych podzespołów prototypowych zainstalowanych $w$ pojazdach szynowych na terenie użytkownika jak $i$ wtasnym wraz z nadzorem dokumentacyjnym i merytorycznym.

10. Badania pojazdów szynowych głównie w zakresie bezpieczeństwa oraz zagadnień rozwojowych, przez akredytowane laboratorium posiadajace uznanie Kolei Niemieckich (Anerkennung Eisenbahn-Bundesamt). Akredytacja krajowa PCA wg normy PN-EN ISO/IEC 17025 [2].

11. Certyfikacja wyrobów $w$ zakresie pojazdów szynowych oraz elementów ich wyposażenia $w$ oparciu o wyniki badań i analiz wykonywanych przez niezależnych specjalistów, nie będacych autorami certyfikowanych wyrobów. Akredytacja krajowa wg normy PN-EN 45011 [3].

Instytut współpracuje z krajowymi i zagranicznymi producentami i użytkownikami pojazdów szynowych wykonując na ich zamówienie opracowania dokumentacyjne, badania dostarczanych obiektów oraz ekspertyzy i oceny mające zastosowanie w procesach certyfikacji wyrobów.

\subsection{Podstawy polityki jakości}

Klientami Instytutu „TABOR” są producenci i użytkownicy pojazdów szynowych, zainteresowani rozwiązywaniem problemów występujących w procesach projektowania, rozwoju, produkcji, instalacji i serwisowania.

Celem naczelnym polityki Instytutu jest zaspokajanie oczekiwań naszych Klientów oraz utrzymywanie i rozwijanie naszego wizerunku jako użytecznej i wiarygodnej jednostki badawczo- rozwojowej, działającej w systemie jakości wg normy PN-EN ISO 9001 [1].

Dla realizacji wymienionej tematyki Instytut angażuje niezbędny potencjał intelektualny, organizację $i$ bazę materialną:

a. Kadre naukowq i inżynierska posiadajacq kompetencje merytoryczne oraz odpowiednie doświadczenie,

b. Kadre technologiczno- wykonawczq z kompetencjami $w$ dziedzinie produkcji elementów oraz ich instalowania i serwisowania,

c. Strukture organizacyjna, wyodrębniajaca komórki specjalistyczne oraz zapewniajaca wspótprace $w$ rozwiazywaniu problemów interdyscyplinarnych, niezależność $i$ obiektywizm poszczególnym specjalistom $w$ aspekcie badań i certyfikacji wyrobów,

d. Stanowiska projektowania komputerowego $z$ niezbędnym oprogramowaniem kompatybilnym $w$ stosunku do krajowych i zagranicznych partnerów w branży pojazdów szynowych, e. Bazy danych normalizacyjnych, katalogowych $i$ literaturowych, niezbędne do projektowania oraz prac rozwojowych,

f. Wyposażenie do przetwarzania $i$ archiwizowania danych elektronicznych, emitowania dokumentacji, wykonywania obliczeń, symulacji $i$ analiz, w oparciu o stosowne oprogramowania,

g. Laboratorium badawcze odpowiednio wyposażone $i$ ukierunkowane na badania pojazdów szynowych i ich wyposażenia,

h. Ośrodek certyfikacji wyrobów dokonujacy ocen pojazdów szynowych i elementów ich wyposażenia na uzytek certyfikacji obowiazkowej i dobrowolnej, wymaganej przez krajowe jednostki kontrolujace oraz producentów i użytkowników.

Dyrekcja Instytutu zapewnia bezstronność działań poszczególnym segmentom systemu jakości poprzez autonomię organizacyjna $i$ niezależność ocen ekspertów, chroniqc ich od nacisków finansowych i działań komercyjnych.

Dokumenty Systemu Jakości sq znane personelowi na poszczególnych stanowiskach pracy $i$ podlegaja okresowym przegladom i aktualizacji, a działanie systemu jest na bieżqco analizowane, uzupetniane i doskonalone.

Dyrektor Instytutu zapewnia niezbędne warunki organizacyjne $i$ materialne dla plynnego funkcjonowania systemu jakości, majac na uwadze przede wszystkim zadowolenie Klientów $i$ wiarygodność Instytutu.

\subsection{System jakości w pracach rozwojowych wg [1] (Certyfikat TüV)}

Podstawą działania systemu jest polityka jakości prowadzona przez Dyrekcję Instytutu. Obejmuje projektowanie, rozwój i doradztwo w dziedzinie pojazdów szynowych oraz produkcję, instalowanie i serwisowanie zespołów w pojazdach szynowych.

System oparty jest na podejściu procesowym, uwzględniającym specyfikę organizacyjną i profil działania firmy. Każdy proces jest opisany w procedurze, która określa parametry wejścia i wyjścia oraz punkty krytyczne wraz z kryteriami ich oceny. Warunkiem postępowania procesu jest zrealizowanie każdego etapu, uzyskanie pozytywnej oceny czyli osiagnięcie zakładanego celu i wymaganych parametrów.

Podstawowym procesem jest pełny cykl projektowania i rozwoju wyrobu, zawierający elementy koncepcji, założeń, analiz, obliczeń, konstruowania, weryfikacji, walidacji wraz z badaniami konstruktorskimi, odbiorczymi i dopuszczeniem do eksploatacji. Proces podlega dokumentowaniu w karcie projektu w układzie podziału na etapy i zadania. Każdy etap i zadanie jest zdefiniowane poprzez dane wejściowe, zakres prac, formę dokumentacji, termin, prowadzącego, 
weryfikatora i zatwierdzającego, który zezwala na realizację kolejnego kroku. Pozwala to na ciagłe monitorowanie przebiegu procesu i podejmowanie decyzji o dalszym awansowaniu prac, pod warunkiem poprawnego przebiegu etapu poprzedniego.

Ze względów technologiczno-organizacyjnych wyodrębniono proces produkcyjny dla wyrobów prototypowych oraz ich serwisowania. Przewiduje on realizację wyrobu w oparciu o umowę, technologię i etapową kontrolę. Wyrób jest odbierany na zgodność z dokumentacją i badany w oparciu o specyfikację badań. Czynności procesowe podlegają zapisowi. Procesy podstawowe są wspomagane procesami pomocniczymi, np. zakupami materiałów i usług, nadzorowaniem wyposażenia technologicznego, kontaktami $\mathrm{z}$ klientem, szkoleniem personelu itp.

Procesy są ze sobą synchronizowane i doskonalone w oparciu o bieżące zapisy i analizę niezgodności, co jest podstawą do działań korygujących. Całość działań nakierowana jest na zadowolenie klienta, zgodnie $\mathrm{z}$ polityką jakości i deklaracją kierownictwa Instytutu.

Cele zapisane $\mathrm{w}$ polityce i deklaracji podlegają sprawdzeniu podczas auditów. System opiera się na czytelności zamierzeń i działań, które muszą być dokumentowane.

\subsection{System Jakości w Laboratorium wg (Akredytacja PCA)}

System został zaprojektowany w Instytucie i obejmuje swymi procedurami niezbędne działania w laboratorium, zmierzające do zaspokojenia oczekiwań klientów. System jakości jest zgodny z wymaganiami normy PN-EN ISO/IEC 17025:2005[2].

Całość działań wynika z polityki jakości laboratorium zapisanej w księdze jakości.

Polityka jakości Instytutu jest kontynuacja i rozwijanie czterdziestoletnich doświadczeń $w$ badaniach pojazdów szynowych $i$ ich zespotów, utrzymanie kompetencji oraz zaspokajanie potrzeb pomiarowo - badawczych projektantów, producentów i użytkowników taboru szynowego z kraju i zagranicy, stosowanie aktualnie wymaganych metod badawczych, minimalizacja kosztów i terminów, prezentowanie miarodajnych $i$ wiarygodnych wyników badań, niezbędnych dla rozwoju konstrukcji oraz certyfikowania badanych wyrobów.

Do realizacji polityki Laboratorium Badań Pojazdów Szynowych dysponuje nastęujacymi środkami:

- Odpowiednio dobrany i kompetentny personel, który jest na bieżaco szkolony

- Wyposazenie badawczo-pomiarowe będace pod statym nadzorem (wzorcowanie, sprawdzanie, przeglady)

- Pomieszczenia badawcze sq wydzielone i zapewniaja zachowanie odpowiednich warunków otoczenia niezbędnych podczas badań
- Pracownia pomiarowa dla bieżcej obstugi metrologicznej podstawowego wyposazenia badawczo-pomiarowego

- Wyposażeniem badawczo-pomiarowym, które jest na bieżaco uzupetniane i modernizowane.

- Metodami badawczymi, które sq na bieżaco aktualizowane i modernizowane.

- Procedura umożliwiajaca walidacje nietypowych metod badawczych.

Ponadto Laboratorium:

- Stosuje wewnętrzne kontrole jakości badań oraz posiada procedure nadzoru badań, nie spetniajacych wymagań

- W miarę możliwości bierze udziat w międzylaboratoryjnych badaniach porównawczych dla bieżcej kontroli kompetencji

- Wspótpracuje z krajowymi $i$ zagranicznymi ośrodkami branżowymi oraz na bieżaco śledzi i wdraża zmiany $w$ normach $i$ innych przepisach dotyczacych badań

- Chroni interesy Klienta w zakresie dostępu do rozwiqzań konstrukcyjnych $i$ wyników badań przed dostępem konkurencji i osób niepowołanych oraz wspótpracuje z klientem na każdym etapie realizacji badań

- Zachowuje bezstronność w badaniach poprzez oddzielenie organizacyjne struktur badawczych od pozostalych komórek Instytutu

- Zaopatruje się $w$ przyrzady pomiarowe, urzadzenia, ustugi i materiaty pomocnicze u kwalifikowanych dostawców.

- Bieżaco doskonali i rozwija swój system zarzadzania.

Za Polityke Jakości w Laboratorium odpowiada Dyrektor a za realizacje Polityki Kierownik Laboratorium.

Personel Laboratorium zna i rozumie polityke jakości, a dokumenty jakości sq mu dostępne i znane oraz stosowane $w$ praktyce.

Laboratorium działa bezstronnie $i$ niezależnie a wynagrodzenie personelu nie zależy bezpośrednio od liczby badań, ani nie jest $w$ żaden sposób zwiazane z ich wynikami.

\subsection{Certyfikacja wyrobów wg [3]}

Certyfikacja wyrobów jest procesem polegającym na porównaniu wyników badań wykonanych przez niezależne i kompetentne laboratorium, $\mathrm{z}$ wyspecyfikowanymi wymaganiami technicznymi dotyczacymi danego wyrobu. Efektem końcowym certyfikacji jest formalne potwierdzenie zgodności wyrobu $\mathrm{z}$ wymaganiami zwane certyfikatem wyrobu, a w branży pojazdów szynowych tymczasowo świadectwem dopuszczenia. Certyfikacja dotyczy głównie bezpieczeństwa, interoperacyjności, niezawodności, ergonomii i jakości pojazdów szynowych. Certyfikacja może być 
obowiązkowa lub dobrowolna, ale zawsze wymaga dokonania oceny przez wykwalifikowany i kompetentny personel w oparciu o aktualne dokumenty normatywne, techniczne i prawne oraz dyrektywy unijne. Warunki takie spełnia Instytut Pojazdów Szynowych „TABOR”, co znajduje potwierdzenie w działalności statutowej oraz $\mathrm{W}$ codziennej praktyce poprzez umieszczenie Instytutu na liście laboratoriów upoważnionych przez Ministra Infrastruktury do wykonywania badań pojazdów szynowych.

Działalność certyfikacyjna wyrobów branży polega na formalnym spełnieniu wymagań normy PN-EN 45011 [3], co w ogólnym zarysie sprowadza się do:

1) Wyznaczenia osoby odpowiedzialnej za obszar certyfikacji.

2) Wytypowania specjalistów kompetentnych w poszczególnych specjalnościach.

3) Ustanowienia i udokumentowania stosownych procedur postępowania.

4) Wdrożenia przyjętego systemu jakości.

5) Złożenia wniosku i poddania się auditowi Polskiego Centrum Akredytacji (PCA) celem uzyskania certyfikatu potwierdzającego kompetencje w zakresie certyfikacji wyrobów w branży pojazdów szynowych.

6) Wiarygodnego działania wg przyjętego systemu jakości celem bieżącego utrzymania posiadanego certyfikatu, który podlega corocznemu auditowi kontrolnemu.

\section{Oczekiwania klientów}

Sektor gospodarki obejmujący transport szynowy i jego otoczenie przechodzi aktualnie głębokie przekształcenia, wynikające ze zmian struktury gospodarczej i rozszerzenia Unii Europejskiej. Gospodarka rynkowa i konkurencja powoduja, że wzrasta zapotrzebowanie na przewozy specjalizowane, szybkie, o zautomatyzowanym załadunku i rozładunku, ekologiczne, energooszczędne, bezpieczne, wysokowydajne i niezawodne. Ze względu na przemieszczanie ładunków i pasażerów na obszarach wielu przewoźników, istotne znaczenie ma zagadnienie interoperacyjności pojazdów i ich podzespołów oraz infrastruktury, podniesione przez Unię Europejską do rangi dyrektywy [4i5]. Powyższe uwarunkowania stymulują nowe rozwiązania konstrukcyjne, technologiczne, materiałowe i organizacyjne. Duże znaczenie ma szybkość reagowania producentów środków transportu szynowego na wyzwania rynku przewozowego.

W tej sytuacji oczekiwania producentów i użytkowników można scharakteryzować następująco:

1) Krótkie terminy realizacji zamówionych usług.

2) Niska cena usług.

3) Posiadanie przez wykonawcę usług certyfikatów wiarygodności i kompetencji.
4) Zdolność wykonawcy usług do ponoszenia odpowiedzialności prawnej i finansowej za ewentualne błędy i ich konsekwencje, co sprowadza się do posiadania stosownego ubezpieczenia.

5) Wariantowość rozwiązań umożliwiająca elastyczne modelowanie ofert dla odbiorców wyrobu.

6) Możliwość korygowania założeń i wymagań w trakcie projektowania.

7) Otwartość projektu na zmiany poddostawców zespołów i części.

8) Elastyczność projektu w zakresie zmian materiałów i technologii.

9) Wyczerpująca informacja dotycząca wymagań stawianych wyrobom przez różnych odbiorców.

10) Opracowanie programów prób i badań na zlecenie klienta.

11) Uzgodnienia programów badań $z$ jednostkami certyfikującymi wyroby.

12) Minimalizacja czasu przygotowania do badań.

13) Nieobciążanie zleceniodawcy świadczeniami materialnymi i organizacyjnymi.

14) Kompleksowa realizacja badań.

15) Bieżące informowanie zleceniodawcy o przebiegu badań i ich wynikach.

16) Umożliwienie wprowadzania zmian $w$ obiekcie w przypadku nie spełniania wymagań.

17) Powtarzanie badań po wprowadzeniu zmian.

18) Możliwie szybkie przedstawienie raportu (sprawozdania ) z badań.

19) W przypadku wyników negatywnych, przedstawienie analizy przyczyn i zaleceń.

20) Dokonywanie kompleksowych ocen wyrobów, będących podstawą certyfikacji.

21) Merytoryczna promocja wyrobów wobec użytkowników.

\section{Problemy występujące w trakcie realizacji tema- tów}

Współpraca Instytutu „TABOR” z klientami dotyczy szerokiego spektrum zagadnień oraz różnych klientów: małych firm powstałych w wyniku restrukturyzacji i prywatyzacji, nie posiadających dużego kapitału ani zaplecza merytorycznego, oraz znaczących firm zagranicznych, szukających tanich usług w krajach nowego obszaru unijnego.

W trakcie realizacji zlecanych tematów dają się wyróżnić następujące problemy: 
1) Zazwyczaj klient wymaga bardzo krótkiego terminu realizacji, usiłując zyskać na czasie i jak najszybciej wejść na rynek. W przypadku wystapienia zwłoki $\mathrm{w}$ procesie produkcji prototypu, celem dotrzymania terminu realizacji całości, usiłuje się skracać terminy badań.

2) Cena proponowana przez klienta różni się często istotnie od oferty wykonawcy.

3) Coraz trudniej przekonywać klienta o wiarygodności i kompetencjach $\mathrm{w}$ oparciu o minione osiagnięcia i tradycję. Posiadanie certyfikatów jakości dla realizacji procesów badawczo- rozwojowych staje się niezbędne.

4) Ubezpieczenie chroni wykonawce przed konsekwencjami uszkodzenia lub zniszczenia obiektu w trakcie badań oraz błędnymi wynikami pomiarów, a co za tym idzie, błędnymi wnioskami i decyzjami. Taka praktyka wynika z uregulowań unijnych, dotyczących odpowiedzialności firm za wyroby i usługi. Kwota rocznej składki $\mathrm{z}$ tego tytułu bywa znaczna i w przypadku dużych i cennych obiektów lub kontraktów może sięgać rzędu kilkudziesięciu tysięcy euro. Wymaga to od wykonawcy spełnienia wymogów ubezpieczenia swej działalności.

5) Wariantowość rozwiązań projektowych zwiększa istotnie pracochłonność tematu. Nie stanowi problemu, jeżeli jest zapisana w umowie , odpowiednio zaplanowana i skalkulowana. W przeciwnym razie wymaga niekiedy głębokich zmian $\mathrm{w}$ procesie projektowania $\mathrm{i}$ korekty $\mathrm{w}$ umowie, na co nie zawsze klient się zgadza.

6) Korygowanie założeń przez klienta $\mathrm{w}$ trakcie projektowania może wynikać ze zmieniającej się koniunktury na rynku, bądź nie dość wnikliwie przemyślanych koncepcji i braku zdecydowania. Jest to zjawisko znacznie zakłócające realizację tematu i wymaga bezwzględnie korekty ceny i terminu.

7) Otwartość projektu na zmiany dostawców podzespołów i części znacznie rozszerza zakres analiz, wersji rysunków i obliczeń. Nie jest to problemem, jeżeli zostało przewidziane na etapie sporządzania umowy.

8) Elastyczność projektu w zakresie zmian materiałów i technologii.

9) Wyczerpująca informacja dotycząca wymagań stawianych wyrobom przez różnych odbiorców. Instytut nie będąc tu stroną a tylko usługodawca, może na zlecenie klienta opracować projekty dokumentów w zakresie, który odbiorca powinien zaopiniować i zatwierdzić.

10) Praktyka wskazuje, że program badań winien być opracowywany przez twórce projektu, gdyż zna on najlepiej mocne i słabe strony swoich rozwiązań, założenia i wymagania oraz działanie obiektu, mającego być przedmiotem badań, co jest bardzo pomocne przy formułowaniu programu badań. Instytut opracowuje programy badań dla własnych projektów, natomiast na zamówienie klienta wykonuje opracowania programów w oparciu o niezbędną do tego dokumentację, udostępnioną przez klienta.

11) Uzgodnienia programów badań $z$ jednostkami certyfikującymi wyroby winien dokonywać autor programu jako najbardziej kompetentny w sprawach merytorycznych.

12) Minimalizacja czasu przygotowania do badań wynika bezpośrednio ze skracania terminów i minimalizacji kosztów. Jednocześnie należy mieć świadomość, że badania są procesem złożonym, wymagającym działań przemyślanych i angażującym obiekt oraz infrastrukturę znacznej wartości. Ryzyko pomyłki, niedotrzymania warunków badań, uszkodzenia obiektu lub aparatury jest potencjalnie duże i może pociągać za sobą znaczne skutki finansowe. Warto zatem dobrze przygotować się do badań zarówno merytorycznie jak organizacyjnie. Bardzo pomocnym jest $\mathrm{w}$ takim przypadku system jakości $\mathrm{w}$ laboratorium, uwzględniający $\mathrm{w}$ swych procedurach niezbędną ostrożność i postępowanie.

13) Nieobciążanie zleceniodawcy świadczeniami materialnymi i organizacyjnymi jest możliwe do spełnienia przez Instytut, jeżeli zostanie to zapisane $\mathrm{w}$ umowie, a klient zechce za to zapłacić.

14) Kompleksowa realizacja badań jest wymaganiem komfortowym dla klienta, natomiast znacznie trudniejszym dla Instytutu „TABOR”, ponieważ nie wszystkie instytutowe laboratoria są w stanie wykonać tak szeroki zakres badań i nie posiadają aparatury specjalistycznej, by wykonywać rzadkie unikatowe badania, chociaż by ze względów ekonomicznych. W takich szczególnych przypadkach Instytut może podzlecić wybrane badania jednostce wyspecjalizowanej, bądź klient zleci te badania bezpośrednio.

15) Bieżące informowanie zleceniodawcy o przebiegu badań i wynikach należy do dobrych praktyk laboratoryjnych, potwierdza wiarygodność laboratorium i jest w Instytucie stosowane $\mathrm{w}$ zakresie uzgodnionym $\mathrm{z}$ klientem.

16) Instytut informuje klienta o przebiegu badań $i$ umożliwia wprowadzanie zmian $\mathrm{w}$ obiekcie $\mathrm{w}$ przypadku, gdy nie spełnia on wymagań. Zmian dokonuje serwis klienta korzystając często $\mathrm{z}$ doradztwa technicznego odpowiednich specjalistów Instytutu oraz $\mathrm{z}$ pomocy technicznowarsztatowej. Wydłuża to termin zakończenia badań i stanowi podstawę aneksowania umowy. Nie wszyscy klienci to akceptuja. 
17) Powtarzanie badań po wprowadzeniu zmian. Dobra praktyka laboratoryjna wymaga udokumentowania postępowania co do wprowadzonych zmian oraz wyników przed i po zmianach. Klienci niechętnie i nie zawsze to akceptują.

18) Niezwłoczne przedstawienie raportu $z$ badań jest często wymuszane celem uzyskania podstawy rozliczeń finansowych, bądź przedłożenia jak najszybciej dokumentów niezbędnych dla uzyskania świadectwa dopuszczenia.

19) W przypadku wyników negatywnych, na zlecenie klienta Instytut przedstawia analize przyczyn i formułuje zalecenia dla naprawy lub ulepszenia obiektu badań. Praktyki takie są chętnie oczekiwane przez klientów i są dopuszczane przez wymagania akredytacyjne i dobra praktykę laboratoryjną.

20) Dokonywanie ocen zbiorczych wyrobów, będących podstawą do ich certyfikacji. Jest to kompleksowa analiza całości dokumentacji, obliczeń i wyników badań pod kątem spełniania wymagań umowy, norm, kart UIC i innych dokumentów odniesienia, będących podstawą certyfikacji wyrobu. Jest to zatem uczestnictwo w procesie certyfikacji, przy czym pozytywna ocena końcowa nie może być tu formalnie wiążąca bez posiadania akredytacji, autoryzacji i notyfikacji.

21) Merytoryczna promocja wyrobów wobec użytkowników wymaga głębokiej znajomości zagadnień transportu szynowego oraz konstrukcji pojazdów dla różnych specyficznych warunków i wymagań przewoźników. Zdarza się, że klient -producent nie dysponuje odpowiednią kadrą i wówczas czekuje pomocy merytorycznej od wyspecjalizowanej instytucji. Sprowadza się to do opracowania koncepcji, ofert technicznych, analiz i uzasadnień, oraz udziału w naradach i konferencjach a na etapie gotowego wyrobu przygotowania merytorycznych ocen dla jednostek certyfikujących wyrób.

\section{Dalsze kierunki działań doskonalących jakość prac}

Realizacja tematów badawczo-rozwojowych jako usług wysokokwalifikowanych o dużym wkładzie intelektualnym $\mathrm{w}$ świetle wolnorynkowych oczekiwaniach klientów stawia przed Instytutem „TABOR” wysokie wymagania merytoryczne i organizacyjne. Praktyka wskazuje, że oczekiwania klientów oraz działania Instytutu nie zawsze są zbieżne a współpraca wymaga często pokonania wielu trudności. Należy mieć świadomość, że dobra współpraca mieścić się będzie na płaszczyźnie realistycznie wynegocjowanych precyzyjnych zapisów w umowach dwustronnych. Dla Instytutu znaczy to konieczność objęcia obszaru swych działań systemem jakości, czyli nadzorowanym, planowanym działaniem zgodnie z procedurami opartymi o aktualne wymagania techniczne i prawne obowiązujące także klientów, jednostki kontrolujące i certyfikujące na obszarze unijnym. Sprawi to, że partnerzy powinni stosować wspólną terminologię, a postępowanie będzie jasne, jednoznaczne i obiektywne. Takie warunki stwarza System Zapewnienia Jakości (SZJ) opisany w normie [1]. Może on dotyczyć praktycznie każdej organizacji realizującej szeroko rozumiane wytwarzanie i usługi.

Dla firm emitujących zanieczyszczenia środowiska stosuje się dodatkowo normę [6] a dla objęcia spraw bezpieczeństwa i higieny pracy normę [7]. Proponowane rozszerzenie jest aktualnie coraz częściej stosowane i dobrze postrzegane przez klientów. Rozszerzenie SZJ o wyżej wymienione aspekty należałoby jednak rozważyć, biorąc pod uwage wielkość zagrożeń środowiska i zagrożenia w pracy oraz koszty tego rozszerzenia. Wiele jednostek badawczo- rozwojowych posiada już zintegrowane systemy zapewnienia jakości, co podnosi ich wiarygodność oraz porządkuje i ułatwia pracę. Jest to zatem konieczny element organizacji również dla Instytutu „TABOR”.

Odrębnym zagadnieniem w Instytucie jest prowadzenie badań. Zadania te realizuje laboratorium, posiadające akredytację potwierdzająca jego kompetencje techniczne oraz przestrzeganie systemu jakości opisanego w normie [2]. Laboratorium posiada niezbędną dokumentację (księge jakości, procedury, instrukcje) oraz uporządkowany zbiór aparatury pomiarowej. Od roku 1999 laboratorium posiada uznanie kolei niemieckich (Eisenbahn- Bundesamt) w zakresie badań pojazdów szynowych, przedłużone w roku 2005 na kolejne 3 lata. W roku 2006 uzyskało akredytację Polskiego Centrum Akredytacji. Obszar badań jest najbardziej formalnie przygotowanym do pracy $\mathrm{w}$ ramach systemu jakości i wymaga znacznego wysiłku dla utrzymania i doskonalenia organizacji, kompetencji i biegłości. Kolejnym obszarem w pracach Instytutu jest działalność na rzecz certyfikacji wyrobów branży kolejowej [8]. Instytut posiada specjalistów o wysokich kwalifikacjach i doświadczeniu w dziedzinie projektowania i rozwoju pojazdów szynowych i pojazdów do transportu szynowo- drogowego.

Poza podstawową działalnością wykonują oni na zlecenia klientów analizy, obliczenia, opinie i oceny dotyczące bezpieczeństwa, interoperacyjności, niezawodności, ergonomii i jakości pojazdów szynowych. Opracowania te są podstawą do wystawiania świadectw dopuszczenia przez Urząd Transportu Kolejowego, który opiera się w swoich decyzjach na opracowaniach wiarygodnych ekspertów a także na raportach z badań wykonywanych przez akredytowane laboratoria i uznane przez ten Urząd jednostki. 
Opisana wyżej działalność w zakresie merytorycznym wyczerpuje definicję certyfikacji obowiązkowej wyrobów a świadectwo wydawane przez UTK jest forma dopuszczenia pojazdu do eksploatacji na terytorium kraju. Istnieje także znaczny obszar certyfikacji dobrowolnej, dotyczącej wyrobów przeznaczonych dla odbiorców prywatnych oraz dla celów poznawczych, kontrolnych i marketingowych, niezbędnej producentom przed wprowadzeniem produktu na rynek.

Ten obszar certyfikacji może być wykonywany w IPS przez akredytowany i notyfikowany Ośrodek Certyfikacji Wyrobów.

Kadra naukowo-techniczna i potencjał intelektualny Instytutu pozwala rozważać perspektywicznie utworzenie wyodrębnionej, bezstronnej grupy ekspertów jako Jednostki Kontrolującej, działającej w oparciu o ustawy [8i9] oraz normę [10].

\section{Model zintegrowanego systemu jakości dla In- stytutu ,TABOR”}

W zakresie działania Instytutu można rozróżnić trzy obszary, funkcjonujące $\mathrm{wg}$ odrębnych dokumentów odniesienia, które są jednak spójne i kompatybilne, gdyż u ich podstaw leży zasada działań zaplanowanych, wykonywanych przez kompetentny personel, spełniających zasadę powtarzalności i odtwarzalności z udokumentowaniem poszczególnych kroków.

Model taki umożliwi realizację oczekiwań klientów w szerokim zakresie, stworzy warunki rozwoju intelektualnego personelu, przystosowując Instytut do aktualnej sytuacji w branży, $\mathrm{z}$ optymalnym wykorzystaniem posiadanej kadry. Model proponowanego zintegrowanego systemu jakości przedstawiono na rys.1.
Autoryzacja -zakwalifikowanie przez ministra lub kierownika urzędu centralnego właściwego ze względu na przedmiot oceny zgodności, zgłaszającej się jednostki lub laboratorium do procesu notyfikacji. W przypadku IPS „TABOR” dotyczy to Laboratorium oraz Ośrodka Certyfikacji Wyrobów i autoryzacja jest udzielana przez Prezesa Urzędu Transportu Kolejowego na podstawie Ustaw [8i9].

Notyfikacja -zgłoszenie do Komisji Europejskiej i państwom członkowskim UE autoryzowanych jednostek certyfikujących i kontrolujących oraz autoryzowanych laboratoriów, właściwych do wykonywania czynności określonych w procedurach oceny zgodności. W przypadku IPS „TABOR” dotyczy to Laboratorium oraz Ośrodka Certyfikacji Wyrobów i notyfikacja jest zgłaszana do Komisji Europejskiej oraz do państw UE przez ministra właściwego do spraw gospodarki.

\section{Podsumowanie i wnioski}

Napływ technologii, materiałów i usług zagranicznych o dużej konkurencyjności zmusza krajowe jednostki badawczo-rozwojowe do ciagłego doskonalenia usług i obniżania kosztów. Sprzyja temu praca w systemach jakości, powodując uporządkowanie procedur, czynności, optymalizację działań oraz minimalizację błędów i maksymalizację zadowolenia klientów.

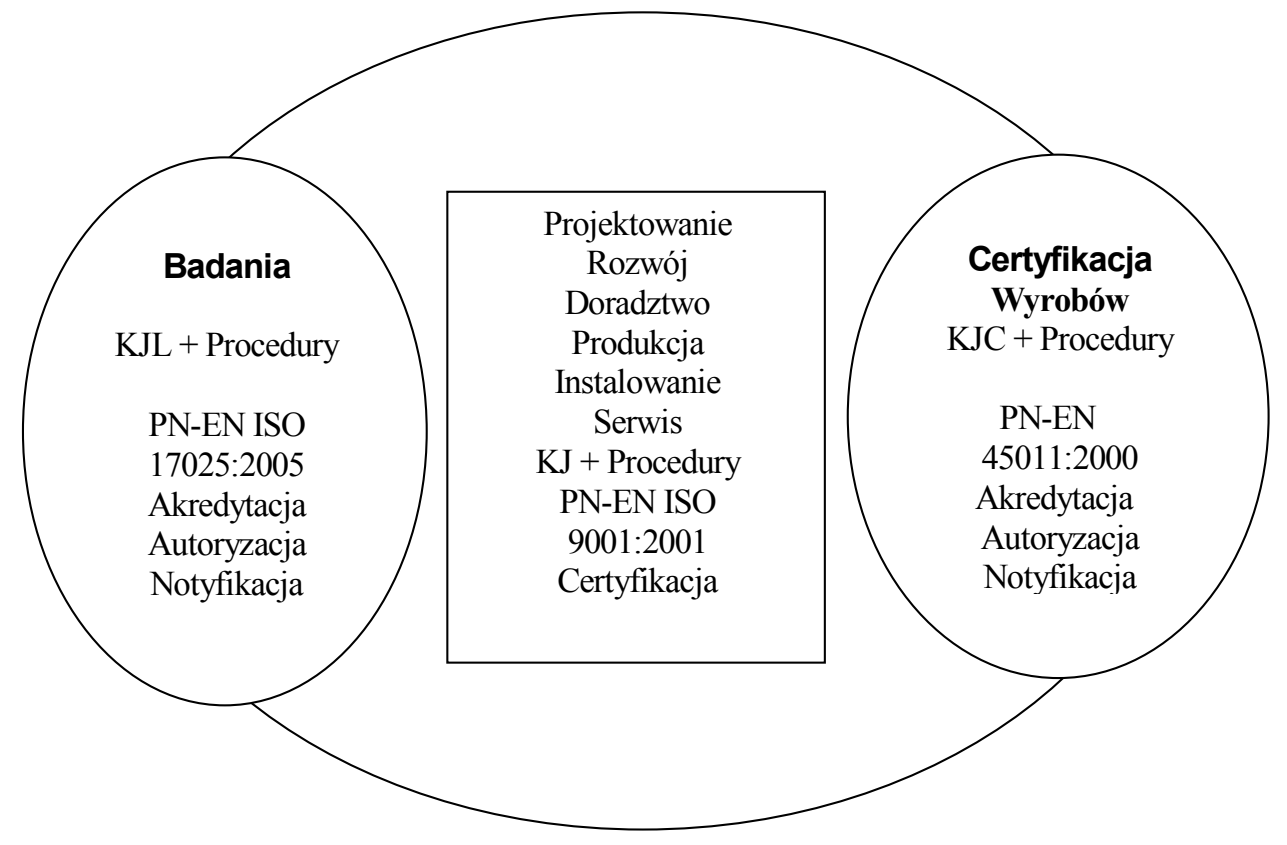

Należy zatem utrzymywać i doskonalić posiadane już uznania, akredytacje i certyfikacje oraz zdobywać nowe, kierując się oczekiwaniami firm współpracujących. Taka polityka jakości winna obejmować cały obszar działań, od projektowania, poprzez rozwój, doradztwo, produkcję jednostkowych wyspecjalizowanych nowości, badania laboratoryjne i eksploatacyjne, do ekspertyz, ocen i certyfikacji wyrobów.

Rys.1 Model zintegrowanego systemu jakości 
Celem utrzymania należnej Instytutowi „TABOR” pozycji w branży pojazdów szynowych w wymiarze krajowym i unijnym niezbędnym standardem byłoby:

1. Dalsze realizowanie zadań statutowych w systemie jakości ISO 9001 [1] w zakresie projektowania, rozwoju, doradztwa, produkcji, instalowania i serwisu oraz bieżące unowocześnianie metod i narzędzi pracy.

2. Dalsze realizowanie badań w laboratorium, w systemie jakości akredytowanym wg EN 17025 [2] i autoryzacji krajowej oraz notyfikacji unijnej jak również bieżące unowocześnianie metod i aparatury pomiarowej.

3. Utrzymywanie i przedłużanie uznania kolei niemieckich na badania pojazdów szynowych.

4. Ocena, opiniowanie i certyfikowanie wyrobów branży pojazdów szynowych w systemie jakości wg EN 45011 [3] i autoryzacji krajowej oraz notyfikacji unijnej.

5. Pozyskiwanie w miarę potrzeb certyfikatów, uznań i uprawnień innych kompetentnych instytucji zagranicznych w branży.

\section{Literatura}

[1] Norma PN-EN ISO 9001: 2001 „Systemy zarzqdzania jakościa. Wymagania."

[2] Norma PN-EN ISO/IEC 17025 :2005 „Ogólne wymagania dotyczace kompetencji laboratoriów badawczych i wzorcujacych".

[3] Norma PN-EN 45011: 2000 „Wymagania ogólne dotyczace jednostek prowadzacych systemy certyfikacji wyrobów".

[4] Dyrektywa 2001/16/EC z 19. 03.2001 „W sprawie interoperacyjności transeuropejskiego systemu kolei konwencjonalnych”. (Dz. Urz. WE L 110, z 20.04. 2001 r.)

[5] Dyrektywa 96/48/WE z 23. 07. 1996 „, W sprawie interoperacyjności transeuropejskiego systemu kolei dużych prędkości”. (Dz. Urz. WE L235, z 17.09. 1996 r.)

[6] Norma PN-EN ISO 14001:2005 „Systemy zarzadzania środowiskowego. Wymagania $i$ wytyczne stosowania."

[7] Norma PN-EN-18001:2004 „Systemy zarzadzania bezpieczeństwem i higiena pracy. Wymagania."

[8] Ustawa z dnia 30 sierpnia 2002 r. o systemie oceny zgodności. (Dz. U. Nr 166, poz.1360)

[9] Ustawa z dnia 20 kwietnia 2004 r. o zmianie ustawy o transporcie kolejowym. (Dz. U. Nr 86, poz. 789)

[10] PN-EN ISO/IEC 17020:2005 „Ogólne kryteria działania różnych rodzajów jednostek kontrolujacych". 